\title{
Sistem Pengelolaan Sampah Di Tpst 3r Tembokrejo Kecamatan Muncar Banyuwangi
}

\author{
Agestin Awalin Kartika*1 $^{\text {, Septa Indra Puspikawati }}{ }^{2}$ \\ ${ }^{1 .}$ Departement of Evironmental Health, Faculty of Public Health, Airlangga University, \\ Indonesia \\ 2. Departement of Health Nutrition, Faculty of Public Health, Airlangga University, \\ Indonesia
}

\section{Author's Email Correspondence (*):agestin.awalin.kartika-2016@fkm.unair.ac.id $(+6289602195986)$}

\begin{abstract}
ABSTRAK
Meningkatnya masalah persampahan di berbagai Kabupaten di Indonesia dapat menimbulkan dampak terhadap pencemaran lingkungan. Menurut kementerian lingkungan hidup dan kehutanan, jumlah timbulan sampah secara nasional sebesar 175.000 ton/hari atau 64 juta ton/tahun dengan komposisi jenis sampah organik sebesar 50\%, plastik sebesar $15 \%$, kertas sebesar $10 \%$ dan sisa sampah lainnya seperti logam, karet, kain, kaca dan lainnya. Kabupaten Banyuwangi merupakan wilayah yang terletak di Provinsi Jawa Timur memiliki jumlah timbulan sampah sebanyak 39,67 ton/hari untuk wilayah kota dan untuk Kabupaten Banyuwangi sebanyak 560,35 ton/hari. Salah satu upaya dalam pengelolaan sampah yaitu dilakukan di Tempat Pengelolaan Sampah Terpadu (TPST) 3R. Penelitian ini bertujuan untuk mengetahui sistem pengelolaan sampah di TPST 3R Tembokrejo Kecamatan Muncar Kabupaten Banyuwangi. Penelitian dilakukan menggunakan metode pendekatan deskriptif. Pengumpulan data menggunakan data sekunder dan data primer mengenai sistem pengelolaan sampah yang berlangsung di TPST 3R Tembokrejo. Hasil penelitian menunjukkan bahwa pengelolaan sampah di TPST 3R Tembokrejo telah dilakukan berdasarkan aspek pengelolaan sampah yang terdiri dari aspek kelembagaan, aspek pembiayaan, aspek teknik operasional dan aspek peran serta masyarakat.
\end{abstract}

Kata Kunci: Pengelolaan sampah, TPST 3R, aspek pengelolaan sampah

Published by:

Tadulako University

Address:

Jl.Soekarno Hatta KM 9. Kota Palu, Sulawesi Tengah, Indonesia.

Phone: +628114120202

Email: Preventif.fkmuntad@gmail.com
Article history :

Received : 29012021

Received in revised form : 30012021

Accepted : 30012021

Available online :31 122021 


\begin{abstract}
The increasing number of solid waste problems in various area in Indonesia can have an impact on environmental pollution. According to the Ministry of Environment and Forestry of The Republic of Indonesia, the national solid waste generation amount is 175,000 tonnes/day or 64 million tonnes/year, consisting of 50\% organic waste, 15\% plastic, 10\% paper, and other waste such as metal, rubber, cloth, glass, and others. Banyuwangi is an eastern town of East Java Province, which has a total solid waste generation of 560.35 tons/day with 39.67 tons/day of waste from the urban area. One of the waste management efforts is to build an Integrated Waste Management Site (TPST) based on the 3R. This study aims to determine the waste management system in TPST 3R Tembokrejo, Muncar District, Banyuwangi. The study was conducted using a descriptive approach method. Data collection used secondary data and primary data regarding the waste management system that takes place at TPST 3R Tembokrejo. The results showed that the waste management at TPST $3 R$ Tembokrejo has been implemented following the waste management aspects consisting of institutional aspects, financing aspects, operational technical aspects and community participation aspects.
\end{abstract}

Keywords: Waste management, TPST 3R, waste management aspects

\title{
PENDAHULUAN
}

Setiap aktifitas yang dilakukan oleh manusia dapat menghasilkan sampah. Apabila pembuangan sampah dilakukan secara terus menerus, maka dapat menimbulkan penumpukan sampah secara berlebihan. Penumpukan sampah yang berlebihan dikhawatirkan dapat menimbulkan dampak bagi lingkungan seperti membuat kualitas lingkungan menurun, penyumbatan saluran air yang nantinya berdampak pada banjir, terjadinya pencemaran lingkungan, bahkan dapat meningkatkan penyakit yang ditularkan oleh vektor maupun rodent dan menimbulkan masalah pada kesehatan masyarakat. Dampak lingkungan dan kesehatan yang diakibatkan oleh sampah dapat menjadi permasalahan penting dan harus ditangani serta dilakukan pengelolaan sehingga nantinya tidak berpengaruh pada lingkungan dan kesehatan masyarakat (1).

Meningkatnya masalah persampahan di berbagai Kabupaten di Indonesia juga dapat disebabkan oleh laju urbanisasi yang cukup tinggi di berbagai wilayah kabupaten yang tidak diimbangi dengan penyediaan infrastruktur persampahan yang memadai. Banyaknya sampah yang dihasilkan suatu daerah juga sebanding dengan jumlah penduduk, jenis kegiatan dan tingkat konsumsi penduduk terhadap suatu barang. Semakin banyak jumlah penduduk atau tingkat konsumsi terhadap suatu barang maka semakin besar pula volume sampah yang dihasilkan. Permasalahan persampahan yang terjadi secara nasional umumnya terjadi pada wilayah yang memiliki keterbatasan lahan TPA sehingga dapat menimbulkan dampak terhadap pencemaran lingkungan. Diperlukan upaya perbaikan dari berbagai pihak dalam menangani masalah persampahan yang terjadi agar lingkungan menjadi nyaman dan bersih (2). 
Menurut Undang-Undang Republik Indonesia Nomor 18 Tahun 2008 tentang Pengelolaan Sampah, disebutkan bahwa sampah adalah sisa kegiatan sehari-hari manusia dan atau proses alam yang berbentuk padat. Pengelolaan sampah rumah tangga dan sejenis sampah rumah tangga diarahkan pada kegiatan yang terdiri dari pengurangan sampah dan penanganan sampah. Pengurangan sampah dapat dilakukan dengan pembatasan timbulan sampah, pendauran ulang sampah dan pemanfaatan kembali sampah dengan metode 3R (reuse, reduce, recycle). Sedangkan penanganan sampah dapat dilakukan melalui, pewadahan, pemilahan, pengumpulan, pengangkutan, pengolahan dan pemrosesan akhir dengan menggunakan berbagai sarana dan prasarana persampahan yang tersedia. Sistem pengelolaan sampah harus dilakukan secara tepat, terintegrasi dan sistematis (3).

Menurut kementerian lingkungan hidup dan kehutanan, jumlah timbulan sampah secara nasional sebesar 175.000 ton/hari atau 64 juta ton/tahun dengan komposisi jenis sampah organik sebesar 50\%, plastik sebesar 15\%, kertas sebesar $10 \%$ dan sisa sampah lainnya seperti logam, karet, kain, kaca dan lainnya. Sumber sampah berasal dari rumah tangga sebesar 48\%, pasar tradisional sebesar 24\%, kawasan komersial sebesar $9 \%$ dan sisanya dari fasilitas publik, jalan, kantor, sekolah dan lainnya (4).

Kabupaten Banyuwangi merupakan wilayah yang terletak di Provinsi Jawa Timur yang dikenal sebagai kota Pariwisata, dimana perkembangan pariwisata yang pesat meningkatkan jumlah pengunjung dan jumlah penduduk yang juga dapat meningkatkan produksi sampah. Jumlah timbulan sampah yang ada di Kota Banyuwangi menurut data sistem informasi pengelolaan sampah nasional KLHK adalah 39,67 ton/hari dan untuk Kabupaten Banyuwangi sebanyak 560,35 ton/hari (4).

Kabupaten Banyuwangi yang juga sebagai salah satu kota penerima adipura terus berbenah dalam mengatasi masalah sampah. Berbagai upaya yang telah dilakukan dalam pengelolaan sampah yaitu dengan melakukan pemilahan sampah di TPS dan DEPO, pengomposan, pembentukan dasawisma yang bertujuan untuk memberikan pengertian kepada masyarakat dalam mengelola sampah yang dihasilkan, serta terbentuknya bank sampah dan Tempat Pengelolaan Sampah Terpadu (TPST) 3R (5).

Keberadaan TPST 3R di Kabupaten Banyuwangi bertujuan untuk membantu pengelolaan sampah di masing-masing desa dikarenakan pelayanan pemerintah yang terbatas dengan luas wilayah dan biaya operasional yang terbatas. Salah satu wilayah yang telah menjalankan program TPST 3R di Kabupaten Banyuwangi yaitu TPST 3R di Desa 
Tembokrejo Kecamatan Muncar. Pelaksanaan program TPST 3R di Desa Tembokrejo mendapatkan antusiasme dari warga dan pemerintah dalam menangani masalah sampah yang berada di wilayah Desa Tembokrejo. Keberadaan sampah yang dulunya telah menyelimuti pasir di sepanjang pesisir pantai akibat tumpukan sampah yang dibiarkan terjadi selama bertahun-tahun disebabkan oleh kebiasaan buruk masyarakat salah satunya dapat diatasi dengan pelaksanaanya program TPST 3R di Desa Tembokrejo. Sebagian besar penduduk membuang sampah tidak pada tempatnya dan membuangnya sembarangan di sungai, laut, kebun, ataupun dibakar serta tidak terdapat sistem pengambilan sampah di daerah pinggiran atau perdesaan (6).

TPST 3R di Desa Tembokrejo dalam melaksanakan pengelolaan sampah mencanangkan program dengan nama STOP (Stopping the Tap on Ocean Plastics) yang mendapatkan pendampingan dari organisasi non pemerintah dan melibatkan Badan Usaha Milik Desa (BUMDES). BUMDES diberikan pelatihan untuk mengoptimalkan sistem pengangkutan, pengumpulan, hingga pengelolaan sampah. Pelaksanaan program STOP memiliki tujuan untuk mencegah adanya sampah yang masuk ke lingkungan dan menyebabkan pencemaran terhadap lingkungan, meningkatkan efisiensi sumber daya dan mendaur ulang plastik, serta memberikan lapangan pekerjaan baru bagi masyarakat setempat dalam pengelolaan sampah. Dalam mencapai tujuan program STOP dibutuhkan pelaksanaan pemberdayaan masyarakat lokal dalam pengelolaan sampah yang baik, terdapat tim yang berada di lapangan, adanya dukungan berupa material dalam keberlangsungan pengelolaan sampah, serta adanya komitmen dari pemerintah untuk mendukung pelaksanaan pengelolaan sampah di TPST 3R Tembokrejo.

Program penanganan sampah di TPST 3R Desa Tembokrejo telah menjadikan kondisi lingkungan wilayah Desa Tembokrejo semakin membaik. Terdapat perubahan perilaku masyarakat dan menimbulkan tumbuhnya kesadaran peduli terhadap sampah serta Desa Tembokrejo menjadi desa percontohan bagi desa-desa lain di Banyuwangi. Oleh karena itu dengan mengingat pencapaian yang telah dilakukan oleh TPST 3R Tembokrejo dilakukan penelitian untuk mengetahui sistem pengelolaan sampah di TPST 3R Tembokrejo Kecamatan Muncar Kabupaten Banyuwangi.

\section{METODE}

Penelitian ini menggunakan metode pendekatan deskriptif yang bertujuan untuk menggambarkan keadaan objek penelitian pada saat penelitian berlangsung berdasarkan fakta yang ada. Lokasi penelitian ini dilaksanakan di TPST 3R Tembokrejo Kecamatan Muncar 
Kabupaten Banyuwangi.

Pengumpulan data dan informasi menggunakan data sekunder yang diperoleh dari data dan dokumen yang sudah ada berupa laporan, arsip atau bahan yang merupakan dokumen resmi dari Dinas Lingkungan Hidup mengenai sistem pengelolaan sampah, sedangkan data primer diperoleh dari indepth interview, diskusi dan tanya jawab serta observasi secara langsung mengenai sistem pengelolaan sampah yang berlangsung di TPST 3R Tembokrejo. Data primer yang diambil meliputi timbulan sampah, pengelolaan persampahan, serta aspek teknis operasional pengelolaan sampah di TPST 3R Tembokrejo.

\section{HASIL}

\section{Sejarah TPST 3R Tembokrejo Kecamatan Muncar Kabupaten Banyuwangi}

Berawal dari permasalahan tumpukan sampah di sepanjang pesisir pantai yang dibiarkan terjadi selama belasan tahun. Metode pembuangan sampah yang dilakukan di Kecamatan Muncar yaitu membuang sampah ke sungai atau laut, dikubur, dibuang ke kebun, dibakar, diambil oleh petugas kebersihan dan dibawa ke TPS terdekat dengan persentase sebagai berikut :

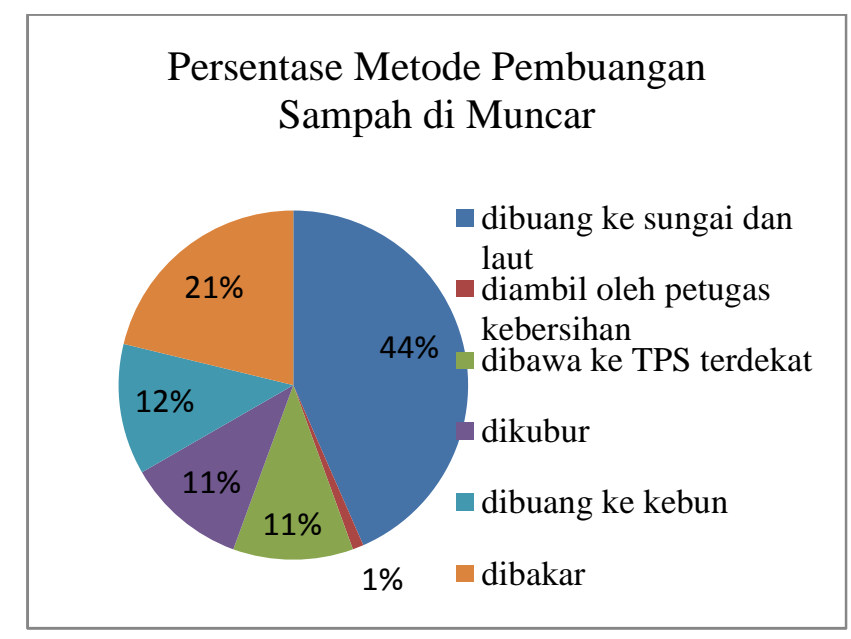

Sumber : Systemiq, 2019

Salah satu cara dalam mengatasi masalah sampah yaitu dengan pembentukan TPST 3R. TPST 3R Tembokrejo dalam melaksanakan pengelolaan sampah yang berada di Muncar mendapatkan pendampingan dari organisasi non pemerintah Systemiq yang mendapatkan dana dari pemerintah Norwegia dan institusi bisnis Borealis dari Australia. Systemiq mencanangkan program dalam penanganan sampah yang bernama STOP (Stopping the Tap on Ocean Plastics). Dalam pelaksanaan pengelolaan sampah juga melibatkan Badan Usaha Milik Desa (BUMDES). BUMDES diberikan pelatihan untuk mengoptimalkan sistem 
pengangkutan, pengumpulan hingga pengelolaan sampah. Sampah yang berasal dari rumah warga kemudian dipilah dan dikelola.

Pelaksanaan program STOP memiliki tujuan untuk mencegah adanya sampah yang masuk ke lingkungan dan menyebabkan pencemaran terhadap lingkungan, meningkatkan efisiensi sumber daya dan mendaur ulang plastik, serta memberikan lapangan pekerjaan baru bagi masyarakat setempat dalam pengelolaan sampah dan mengurangi dampak pengelolaan sampah yang tidak benar terhadap sektor kesehatan masyarakat, pariwisata dan perikanan.

\section{Timbulan Sampah di TPST 3R Tembokrejo}

Berdasarkan data hasil pencatatan tentang sampah yang masuk di TPST 3R Tembokrejo, sampah terdiri dari sampah plastik, sampah serlain anorganik, sampah anorganik, sampah organik dan sampah residu. Komposisi sampah residu sebagian besar adalah popok sekali pakai (diapers), pembalut, putung rokok dan sebagainya, sehingga residu ini sulit untuk diolah. Pada tahun 2019 jumlah timbulan sampah di TPST 3R adalah sebanyak 3.172 ton. Berikut data hasil pencatatan timbulan sampah yang terjadi secara fluktuatif di TPST 3R Tembokrejo:

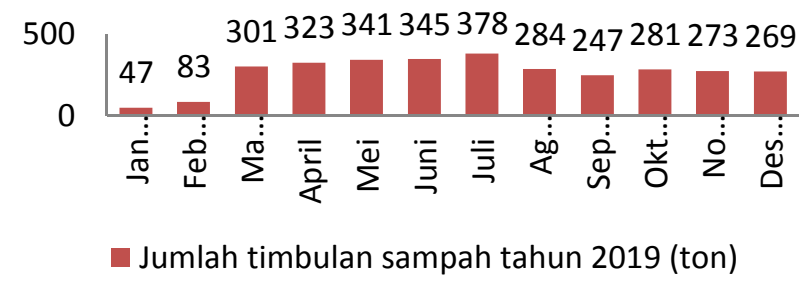

Sumber : Systemiq, 2020

Dari jumlah timbunan sampah yang masuk ke TPST 3R Tembokrejo diketahui sumber sampah terdiri dari beberapa macam jenis yang dibedakan menjadi sampah plastik, sampah selain anorganik, sampah organik, sampah anorganik, sampah organik dan sampah residu. Berikut merupakan persentase dari jenis timbulan sampah di TPST 3R Tembokrejo, Kecamatan Muncar 


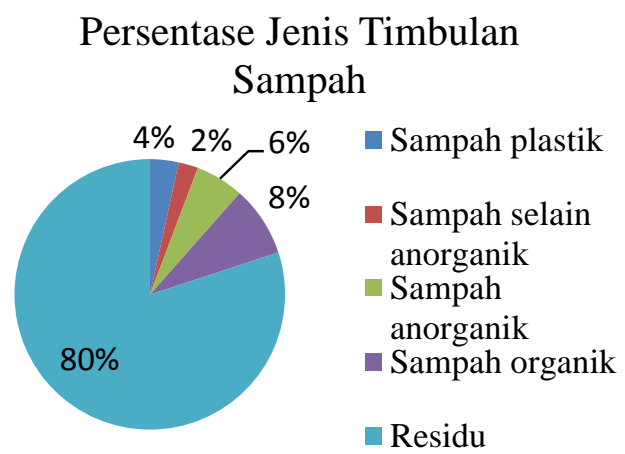

Sumber : Systemiq, 2020

\section{Aspek Hukum Sistem Pengelolaan Sampah di TPST 3R Tembokrejo}

Pelaksanaan pengelolaan sampah yang berada di TPST 3R Tembokrejo Kecamatan Muncar Kabupaten Banyuwangi mengacu pada beberapa peraturan terkait yang dapat dijadikan sebagai landasan hukum yang kuat bagi penyelesaian kasus sampah di Muncar yaitu :

1. Undang-undang Nomor 18 tahun 2008 tentang Pengelolaan Sampah

2. Peraturan Presiden RI Nomor 97 tahun 2017 tentang Kebijakan dan Strategi Nasional Pengelolaan Sampah Sejenis Sampah Rumah Tangga

3. Peraturan Daerah Nomor 9 tahun 2013 tentang Pengelolaan Sampah Rumah Tangga dan Sampah Sejenis Rumah Tangga

4. Peraturan Desa Tembokrejo Nomor 2 tahun 2019 tentang Pengelolaan Sampah

\section{Aspek Kelembagaan dalam Pengelolaan Sampah}

Kelembagaan dalam pengelolaan sampah di TPST 3R Tembokrejo dilaksanakan oleh Kelompok Swadaya Masyarakat/ KSM Bio Mandiri Lestari yang dibentuk melalui rembug warga Desa Tembokrejo. KSM Bio Mandiri Lestari dibentuk sebagai upaya warga Desa Tembokrejo untuk melakukan pengelolaan sampah di seluruh wilayah Desa Tembokrejo. Berikut susunan pengurus pengelolaan sampah KSM Bio Mandiri Lestari : 


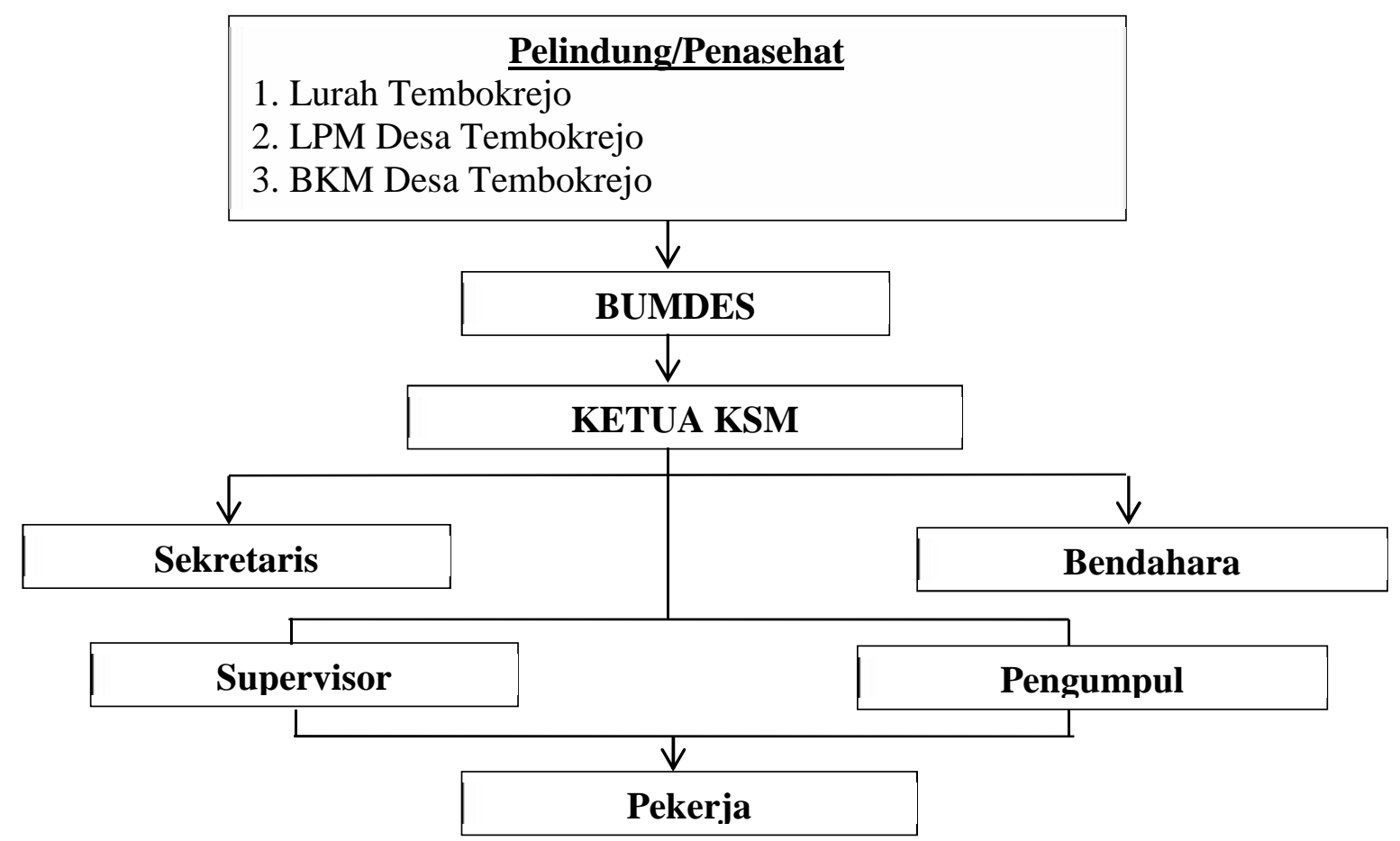

Sumber : Systemiq,2019

Susunan pengurus KSM Bio Mandiri Lestari yang merupakan suatu organisasi kemasyarakatan bersifat sosial dan bergerak di bidang pengelolaan lingkungan di Desa Tembokrejo memiliki bentuk kegiatan pengelolaan sampah yang dilaksanakan sejak dari rumah tangga hingga ke TPST 3R. Terdapat tugas dan fungsi dari KSM Bio Mandiri Lestari yaitu :

1. Tugas KSM Bio Mandiri Lestari

a. Membantu pemerintah dalam pelayanan kepada masyarakat di bidang kebersihan lingkungan hidup, khususnya pengelolaan sampah di Desa Tembokrejo

b. Meningkatkan kesejahteraan sosial masyarakat yang berasal dari pengelolaan sampah

c. Meningkatkan kepedulian serta peran serta masyarakat dalam kebersihan lingkungan

2. Fungsi KSM Bio Mandiri Lestari

a. Menyusun perencanaan jangka pendek, menengah dan panjang berdasarkan potensi lingkungan yang ada

b. Mengumpulkan serta menyusun laporan pertanggung jawaban sumber-sumber keuangan yang diperolehnya secara berkala kepada Kepala Desa Tembokrejo 
c. Melaksanakan pengangkutan sampah secara efektif dan efisien dengan memperhatikan dampak lingkungan di sekitar tempat pengolahan

d. Melaksanakan koordinasi dengan berbagai kalangan dalam rangka meningkatkan mutu lingkungan hidup yang ada di Desa Tembokrejo

\section{Aspek Pembiayaan dalam Pengelolaan Sampah}

Dalam pelaksanaan pelayanan dan pengelolaan sampah di TPST 3R Tembokrejo Kecamatan Muncar, Kabupaten Banyuwangi sumber biaya operasional berasal dari :

1. Dana iuran masyarakat (public contribution fund)

Dana iuran masyarakat merupakan dana yang berasal dari masyarakat melalui kesepakatan retribusi untuk kebutuhan biaya operasional pengumpulan sampah dan operasional penyelenggaraan TPST 3R serta pemeliharaan sarana prasarana yang dilakukan secara bulanan. Penentuan iuran ditentukan melalui musyawarah dan disepakati untuk iuran warga yang dihitung per rumah dan iuran bulanan sampah tersebut berkisar Rp. 10.000 untuk rumah tangga dan \pm Rp. 50.000 untuk usaha/bisnis yang telah disepakati bersama dan diatur dalam Peraturan desa Nomor 2 tahun 2019 tentang pengelolaan sampah.

2. Pendapatan penjualan (sales revenue)

Dana ini berasal dari hasil penjualan dari pengelolaan sampah organik seperti kompos dan larva lalat BSF (Black Soldier Fly) serta dari pengelolaan sampah anorganik yang telah dipilah seperti plastik dan non plastik.

3. Dana desa (Village fund)

Dana desa merupakan dana yang bersumber dari APBN yang diperuntukkan bagi desa yang ditransfer melalui anggaran belanja daerah kabupaten/kota. Alokasi dana desa yang digunakan untuk pelaksanaan pengelolaan sampah diberikan oleh desa untuk pengelolaan sampah di TPST 3R Tembokrejo

\section{Aspek Teknik Operasional Pengelolaan Sampah}

Berikut merupakan skema pelaksanaan sistem pengelolaan sampah di TPST 3R Tembokrejo pada aspek teknik operasional pengelolaan sampah : 
Skema Sistem Pengelolaan Sampah di TPST 3R Tembokrejo Kecamatan Muncar Kabupaten

Banyuwangi

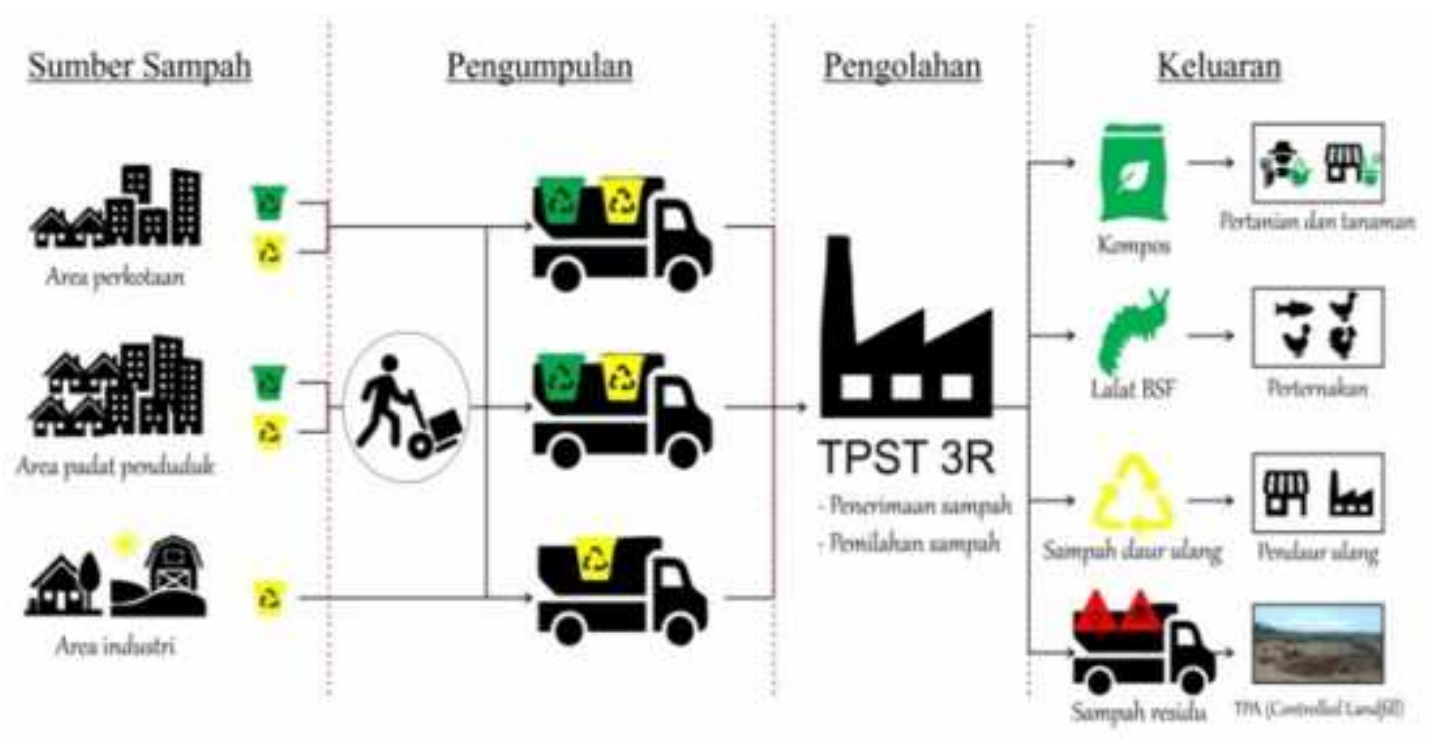

Sumber : Hasil Observasi, 2019

dalam sistem pengelolaan sampah di TPST 3R Tembokrejo terdapat teknik operasional dalam pengelolaannya yaitu :

1. Pewadahan sampah

Pewadahan sampah di Desa Tembokrejo yang merupakan sumber sampah dari masyarakat telah dibedakan menjadi 2 jenis yang berasal dari rumh tangga yaitu sampah organik dan sampah anorganik. Pemberian wadah ini telah diberikan kepada masyarakat desa wilayah Tembokrejo untuk memilah sampah sesuai dengan jenisnya dari rumah. Pewadahan untuk sampah organik diletakkan di bin plastik dengan warna hijau, sampah anorganik diletakkan di bin warna kuning.

2. Pengumpulan sampah

Pengumpulan sampah dilakukan untuk mengumpulkan sampah yang dihasilkan oleh sumber dan dibawa ke suatu titik tempat penampungan yang sudah ditentukan bersama oleh pengelola dan masyarakat. Pengumpulan sampah di Desa Tembokrejo dilakukan dengan menggunakan armada pengangkutan seperti tossa yang berisi beberapa bin untuk memisahkan sampah yang telah terpilah dari sumber timbulan sampah menuju TPST 3R Tembokrejo. Jumlah armada tossa yang terdapat di TPST 3R Tembokrejo sebanyak 13 armada tossa dengan kapasitas maksimal berat sampah yang diangkut adalah $350 \mathrm{~kg} / \mathrm{tossa}$. 
Ritasi armada dalam pengambilan sampah yaitu pada area padat penduduk sebanyak 3 ritasi dan untuk daerah perkotaan sebanyak 2 ritasi.

Metode pengumpulan sampah di TPST 3R Tembokrejo dibedakan menurut area pengambilannya. Pada area perkotaan sampah yang berasal dari rumah tangga telah diletakkan pada tempat yang mudah untuk dijangkau oleh petugas pengumpul sampah untuk diangkut menggunakan armada pengangkutan tossa secara langsung. Pada area padat penduduk yang dimungkinkan susah untuk kendaraan mengangkut langsung sampah, maka diperlukan petugas yang memasuki wilayah dengan membawa bin yang berukuran lebih besar untuk membawa sampah yang berasal dari rumah tangga yang susah dijangkau. Pada area industri sampah anorganik yang telah dikumpulkan dapat diangkut langsung menuju TPST 3R Tembokrejo melalui armada pengangkutan.

3. Penerimaan

Penerimaan sampah di TPST 3R Tembokrejo merupakan fasilitas yang berfungsi sebagai tempat penerimaan awal sampah yang masuk sebelum dilakukan pemilahan berdasarkan jenisnya. Sampah yang diterima adalah sampah yang sudah diangkut dari sumber sampah.

4. Pengolahan

Kegiatan pengolahan sampah yang dilakukan oleh TPST 3R Tembokrejo yaitu dengan melakukan pemilahan sesuai dengan jenis sampahnya dengan bantuan conveyor. Pemilahan sampah dibedakan antara sampah organik dan sampah anorganik.

a. Sampah anorganik

Sampah anorganik yang telah dilakukan pemilahan sesuai dengan macam jenisnya, sampah diletakkan di tempat penyimpanan dan akan dilakukan pengepressan sampah dengan bantuan mesin press. Setelah sampah dilakukan pengepresan sesuai dengan jenisnya, sampah akan disimpan dan dipersiapkan untuk diserahkan kepada pihak ketiga sebagai pendaur ulang sampah anorganik.

b. Sampah Organik

Sampah organik yang telah dilakukan pemilahan digunakan sebagai bahan komposting dan budidaya lalat BSF (Black Soldier Fly) :

1) Komposting

Kegiatan komposting dilaksanakan dari hasil sampah organik yang berada di TPST 3R Tembokrejo. Sampah yang akan dikompos dilakukan pencacahan dengan menggunakan 
mesin pencacah sampah basah dan dilakukan penumpukan sampah pada tempat-tempat yang telah disediakan. Proses pematangan kompos yang siap dilakukan pemanenan yaitu berkisar 3-4 bulan dan mencapai sekitar \pm 1 ton setiap panen. Setelah pemanenan, kompos akan dilakukan pengayakan dan pengemasan.

Dalam proses komposting di TPST 3R Tembokrejo Kecamatan Muncar, jumlah penggunaan sampah organik yang digunakan sebagai bahan untuk komposting yaitu berkisar $500 \mathrm{~kg} /$ hari. Untuk hasil komposting yang telah matang dan telah dilakukan pengemasan, kompos dijual sebagai pemasukan bagi TPST 3R Tembokrejo. Harga penjualan kompos di TPST 3R Tembokrejo yaitu Rp. 1.000/kg atau Rp.10.000 - Rp. 15.000/karung dan 1 karung berisi sekitar 10-15kg kompos. Sedangkan untuk pembelian kompos sebanyak 500-100kg dijual dengan harga Rp. 750/kg.

2) Budidaya Lalat BSF (Black Soldier Fly)

Sampah organik yang terdapat di TPST 3R juga diolah untuk dipergunakan sebagai bahan makanan larva lalat BSF (Black Soldier Fly) atau maggot (Hermetia illucens). Maggot BSF ini dapat mengurai sampah sampai lebih dari 80\% dan 20\% sisanya adalah residu yang tidak dapat diuraikan. Penggunaaan sampah organik seperti nasi, sisa makanan, dan buah-buah an yang dapat dijadikan sebagai bahan makanan maggot BSF di TPST 3R Tembokrejo yaitu sekitar $100 \mathrm{~kg} / \mathrm{hari}$. Masa panen dari maggot BSF ini dapat dilakukan setiap hari yaitu sekitar 30-100kg/hari.

Budidaya maggot dikembangbiakkan untuk dijual ke masyarakat yang dapat digunakan sebagai pakan ternak atau ikan karena memiliki protein tinggi. Harga penjualan berkisar Rp. 5.000 - Rp. 7.000/kg.

Siklus perkembangbiakan BSF di TPST 3R Tembokrejo yaitu :

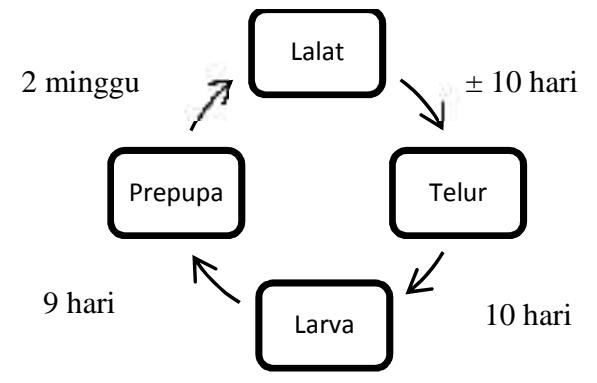

Gambar. Siklus hidup BSF di TPST 3R Tembokrejo

Sumber : Data Primer,2020 


\section{Pengangkutan}

Pengangkutan sampah yang merupakan kegiatan operasi dari titik pengumpulan terakhir atau sampai ke tempat pemrosesan akhir. Pengangkutan yang dilaksanakan oleh TPST 3R Tembokrejo yaitu menggunakan alat angkut dump truck untuk mengangkut sampah residu yang tidak dapat diolah dari tempat pemilahan TPST 3R Tembokrejo menuju tempat pemrosesan akhir (TPA). Proses pengangkutan di TPST 3R Tembokrejo yang dilakukan untuk mengangkat sampah residu ke TPA dilaksanakan setiap hari.

\section{Pemrosesan Akhir}

Proses pengelolaan persampahan di Tempat Pemrosesan Akhir dilakukan di TPA Tegalwero yang berada di Kecamatan Rogojampi Kabupaten Banyuwangi. Metode operasional yang dilakukan dalam pengolahan sampah yaitu dengan metode Controlled Landfill. Pada tempat pemrosesan akhir sampah (TPA) Tegalwero dilakukan kegiatan penanganan sampah dengan cara penimbunan sampah secara berlapis-lapis dan dipadatkan dengan alat berat lalu sampah ditutup dengan menggunakan tanah urug secara bertahap setelah sampah selesai diletakkan di area penimbunan untuk meminimalisir dampak negatif pada lingkungan yang ditimbulkan oleh sampah seperti timbulnya bau, lalat, gas metan dan berkembanya faktor penyakit.

\section{1) Apek Peran Serta Masyarakat dalam Pengelolaan Sampah}

Dalam pengelolaan sampah di TPST 3R Tembokrejo terdapat peran serta masyarakat seperti telah merubah kebiasaan buruk dengan melakukan pembuangan sampah pada tempatnya dengan melakukan pemilahan sampah dari sumber rumah tangga dengan memilah antara sampah organik dan sampah anorganik. Melakukan pembayaran retribusi sesuai dengan kesepakatan meskipun masih belum keseluruhan bersedia untuk membayarnya. Masyarakat juga turut aktif dalam mengikuti kegiatan sosialisasi atau program pengelolaan sampah seperti yang telah dilakukan secara umum maupun individual seperti pada acara pengajian atau PKK maupun door to door.

\section{PEMBAHASAN}

Komposisi timbulan sampah yang terdapat di TPST 3R Tembokrejo cenderung lebih banyak sampah residu. Sampah residu merupakan sampah yang sudah tidak dapat digunakan kembali (reuse), diolah (recycle) ataupun dijadikan kompos dan sudah tidak memiliki nilai ekonomis (8). Pengelolaan sampah residu yang sudah tidak digunakan akan dibuang ke TPA. Pelaksanaan pengelolaan sampah yang dilakukan di TPST 3R melalui beberapa aspek. 


\section{Aspek Kelembagaan Pengelolaan Sampah TPST 3R Tembokrejo}

Kelompok swadaya masyarakat (KSM) Bio Mandiri Lestari yang telah terbentuk melaksanakan pengelolaan sampah di seluruh wilayah Desa Tembokrejo. KSM yang sudah terbentuk tetap dalam kendali dinas lingkungan hidup dan pihak swasta sehingga mudah untuk mengontrol pelaksanaan di lapanagan.

Terbentuknya pengurus pengelolaan sampah di TPST 3R Tembokrejo yang bekerjasama dengan berbagai pihak ataupun dinas terkait diharapkan dapat melaksanaan pengelolaan sampah dengan baik dan dapat mengurangi pencemaran yang ada di lingkungan. Hal ini juga sejalan dengan penelitian Purpasari bahawa peran kelembagaan dalam pengelolaan sampah juga diperlukan. Pelaksanaan pengelolaan sampah di suatu wilayah diperlukan keterlibatan masyarakat, pemerintah, LSM, dan pihak swasta (9).

\section{Aspek Pembiayaan Pengelolaan Sampah TPST 3R Tembokrejo}

Aspek pembiayaan juga menjadi bagian yang sangat penting dalam pengelolaan sampah (10). Keberadaan aspek pembiayaan dapat mempengaruhi aspek teknis operasional dalam penyediaan sarana prasarana pengelolaan sampah. Sumber pembiayaan dalam pengelolaan sampah di TPST 3R Tembokrejo yang berasal dari dana iuran masyarakat, pendapatan penjualan dan dana desa digunakan untuk pelaksanaan pengelolaan sampah dengan penyediaan sarana praarana seperti tempat sampah, sapu, kendaraan pengangkut sampah dan biaya operasional lain yang dilakukan untuk pengelolaan sampah. Dalam aspek pembiayaan untuk pengelolaan sampah diperlukan adanya keterlibatan beberapa pihak seperti masyarakat ataupun aparat pemerintah. Penelitian yang dilakukan oleh Hendra menyatakan bahwa tarif retribusi yang berjalan belum didasarkan pada perhitungan dan pendataan yang memadai serta penarikan biaya retribusi juga rendah. Kerjasama dengan pihak swasta juga diperlukan dalam memenuhi pembiayaan pengelolaan sampah. Kerjasama dapat dilakukan dalam bentuk investasi ataupun Corporate Social Responsibility (CSR) dari perusahaan berupa bantuan sarana dan prasarana seperti tempat sampah, alat angkut, dan pelatihan pengelolaan sampah kepada masyarakat (11).

\section{Aspek Teknik Operasional Pengelolaan Sampah TPST 3R Tembokrejo}

Pelaksanaan teknis operasional pengelolaan sampah di TPST 3R Tembokrejo pada pewadahan sampah dilakukan denganmetode individual dan komunal. Pewadahan individual diletakkan tempat sampah pada setiap sumber sampah seperti di depan rumah masyarakat. 
Pewadahan komunal diletakkan di beberapa titik seperti jalanan umum, taman. Pelaksanaan pewadahan telah dibedakan menjadi sampah organik dan anorganik. Pola pemilahan pewadahan sampah setidaknya dibagi menjadi 3 yaitu sampah organik, sampah anorganik dan sampah B3 rumah tangga. Penempatan wadah dengan metode individual dapat diletakkan di halaman depan sedangkan metode komunal dapat diletakkan dekat dengan sumber sampah dan tidak mengganggu pengguna jalan (12).

Sistem pengumpulan yang menjadi cara dalam proses penanganan sampah dengan mengumpulkannya dari lokasi sumber sampah untuk diangkut ke tempat pembuangan sementara (TPS) atau langsung menuju ke tempat pembuangan akhir (TPA). (13). Pengumpulan sampah di wilayah TPST 3R Tembokrejo dilakukan dengan menggunakan armada pengangkutan pada pewadahan yang sudah dilakukan pemilahan. Menurut hasil wawancara pelaksanaan pengumpulan sampah terkadang masih menggunakan satu bin sehingga menyebabkan sampah yang telah dipisah dari rumah tangga dicampur kembali saat proses pengumpulan sebelum dibawa ke ke lokasi penerimaan TPST.

Proses penerimaan sampah dilakukan untuk menerima sampah yang masuk di TPST 3R Tembokrejo sebelum dilakukan pemisahan berdasarkan jenisnya. Proses pengolahan sampah dilakukan agar sampah dapat memberikan manfaat dan tidak merusak lingkungan. Pemisahan dibedakan antara sampah organik dan sampah anorganik. Hasil pemisahan sampah anorganik yang masih memiliki nilai guna di TPST 3R Tembokrejo dilakukan pendaur ulangan oleh pihak ketiga. Pihak TPST 3R Tembokrejo belum melakukan pendaur ulangan sampah anorganik menjadi bahan kerajinan yang akan menghasilkan nilai jual. Pemanfaatan sampah anorganik dapat di daur ulang dalam berbagai cara misalnya pada sampah yang berbentuk kaca dijadikan sebagai bahan dekorasi, sampah logam menjadi bentuk yang diinginkan melalui proses pemanasan, serta pemanfaatan kain atau kertas menjadi produk daur ulang (14).

Pengolahan sampah organik di TPST 3R digunakan sebagai bahan untuk komposting dan sumber makanan dalam budidaya lalat BSF. Penerapan komposting dalam pengolahan sampah di TPST 3R untuk mendapatkan kompos yang berguna dalam memperbaiki kesuburan tanah dan menjadi media untuk bercocok tanam. Pelaksanaan komposting berguna untuk mengurangi jumlah sampah yang masuk ke TPA sehingga dilakukan pengolahan sampah organik menjadi kompos. Penelitian yang dilakukan oleh indriyanti tahun 2015 menyatakan bahwa pelaksanaan pengolahan limbah organik pada sampah pasar menjadi 
kompos dapat menangani masalah sampah organik dari sisa sayuran yang terbuang dalam jumlah yang cukup banyak setiap harinya. Hasil dari pengomposan yang berupa kompos juga menjadi peluang usaha dan laku terjual [15]. Pengolahan limbah organik juga digunakan sebagai bahan makanan budidaya lalat BSF. Hasil dari pelaksanaan budidaya lalat BSF dapat mengurangi timbulan sampah serta dapat dijadikan sebagai pakan ternak ikan ataupun unggas. Penelitian yang dilakukan oleh Rofi tahun 2020 menunjukkan bahwa hasil pada pelaksanaan budidaya larva BSF dapat mereduksi sampah organik sekitar 33,75\% sampai $46,25 \%(16)$.

Sampah yang tidak dapat diolah dalam TPST 3R Tembokrejo dan tidak memiliki nilai guna akan diangkut menuju TPA. Pengangkutan sampah residu yang dilakukan 1x ritasi dari TPST menuju TPA dapat ditingkatkan agar tidak terjadi penumpukan sampah. Proses pengolahan sampah di TPA menggunakan metode controlled landfill. Penyediaan TPA di kota seharusnya dapat menerapkan metode sanitary landfill. Penempatan jarak lokasi TPA sejauh kurang lebih 500 meter dari permukiman sehingga dapat mengurangi dampak pencemaran air akibat resapan lindi dan penyebaran vektor penyakit ke masyarakat (17)(3).

\section{Aspek Peran Serta Masyarakat dalam Pengelolaan Sampah TPST 3R Tembokrejo}

Masyarakat dapat berperan serta dalam pelaksanaan pengelolaan sampah dimulai sejak dari rumah tangga yang dapat mencapai kunci keberhasilan dari pengelolaan sampah berbasis masyarakat. Upaya yang telah dilakukan oleh masyarakat dalam pengelolaan sampah di wilayah TPST 3R Tembokrejo yaitu dengan melakukan pemilahan sampah dari rumah tangga, pembayaran biaya retribusi, dan mengikuti kegiatan sosialisasi pengelolaan sampah. Penelitian yang dilakukan sulistyorini menyampaikan bahwa partisipasi masyarakat dalam pengelolaan sampah dilakukan dengan memberikan gagasan atau ide dalam menentukan keputusan kebijakan yang akan dilaksanakan, serta terdapat upaya dari masyarakat dalam melakukan usaha pemilahan sampah dan memanfaatkan sampah menjadi produk daur ulang untuk menjaga kebersihan lingkungan (18).

\section{KESIMPULAN DAN SARAN}

Berdasarkan hasil penelitian dan pembahasan mengenai sistem pengelolaan sampah di TPST 3R Tembokrejo dapat disimpulkan :

1. Timbulan sampah yang masuk ke TPST 3R pada tahun 2019 sebanyak 3172 ton dan ratarata 265 ton setiap bulan. Jenis sampahnya terdiri dari $4 \%$ sampah plastik, $2 \%$ selain 
sampah anorganik, 6\% sampah anorganik, 8\% sampah organik dan $80 \%$ merupakan residu yang tidak dapat diolah.

2. Kelembagaan dalam pengelolaan sampah di TPST 3R Tembokrejo dilaksanakan oleh Kelompok Swadaya Masyarakat/ KSM Bio Mandiri Lestari yang dibentuk sebagai upaya dalam melakukan pengelolaan sampah di seluruh wilayah Desa Tembokrejo.

3. Aspek pembiayaan yang digunakan untuk operasional pengelolaan sampah di TPST 3R Tembokrejo berasal dari dana iuran masyarakat, pendapatan penjualan dan dana desa yang telah dialokasikan untuk pengelolaan sampah di Desa Tembokrejo

4. Aspek teknik operasional pengelolaan sampah di TPST 3R Tembokrejo dilakukan dengan pewadahan, pengumpulan, pengolahan, pemilahan antara sampah organik yang digunakan sebagai kompos dan budidaya lalat BSF (Black Soldier Fly) dan sampah anorganik untuk diserahkan ke pihak pengepul, pengangkutan dan pemrosesan akhir di TPA.

5. Peran serta masyarakat dalam pengelolaan sampah di TPST 3R Tembokrejo yaitu masyarakat telah melakukan pemilahan sampah dari rumah, bersedia membayar retribusi sampah yang sudah disepakati, mengikuti kegiatan sosialisasi pengelolaan sampah.

\section{DAFTAR PUSTAKA}

1. Lingkungan hidup. Masalah Sampah Plastik di Indonesia dan Dunia. 2016;

2. Mahyudin R.P. Kajian Permasalahan Pengelolaan Sampah dan Dampak Lingkungan di TPA (Tempat Pemrosesan Akhir). 2017;3(1):66-74.

3. Menteri Hukum dan Hak Asasi Manusia. Undang-Undang Nomor 18 Tahun 2008 tentang Pengelolaan Sampah. Jakarta;

4. Kementrian Lingkungan Hidup. Timbulan Sampah Periode 2017-2018. Sistem Informasi Pengelolaan Sampah Nasional. 2018;

5. Dinas Lingkungan Hidup. Pengelolaan Persampahan Kabupaten Banyuwangi. 2019;

6. Anton Wisuda. Sampah Muncar yang Tak Kunjung Terselesaikan. Banyuwangi; Mongabay; 2019;

7. Borealis, Systemiq. Project STOP (Stop Ocean Plastic) : Stoping Plastic Leakage To The Ocean - Muncar, Banyuwangi. 2019;

8. Paramita, R. Sampah Residu. 2014;

9. Puspasari, GR., Mussadun. Peran Kelembagaan Dalam Pengelolaan Persampahan Di Kabupaten Trenggalek

10. Andrik, F.C,A. Kajian Pembiayaan Sampah Dalam Mendukung Pengelolaan Sampah di Pasar Johar Kota Semarang.2009;

11. Hendra, Y. Perbandingan Sistem Pengelolaan Sampah Di Indonesia dan Korea Selatan : Kajian 5 Aspek Pengelolaan Sampah. 2016; 7(1):77-91. 
12. Badan Standardisasi Nasional. SNI 19-2454-2002. Tata Cara Teknik Operasional Pengelolaan Sampah Perkotaan. 2002;

13. Aspian, S.A. Optimalisasi Pengumpulan dan Pengangkutan Sampah Kota Muara Teweh Melalui Pendekatan Zonasi. Tesis. Universitas Diponegoro. 2009;

14. Fadhilah, A. dkk. Kajian Pengelolaan Sampah Kampus Jurusan Arsitektur Fakultas Teknik Universitas Diponegoro. 2011; 11(21) : 62-71.

15. Indriyanti, D.R, dkk. Pengolahan Limbah Organik Sampah Pasar Menjadi Kompos. 2015; 19(1) : 43-48.

16. Rofi, D.Y. Teknologi Reduksi Sampah Organik Buah dan Sayur Dengan Modifikasi Pakan Larva Black Soldier Fly. 2020;

17. Ngaziizi,A.TPA.2012 